\title{
Chromosome analysis of Mammillaria supertexta, $M$. crucigera and $M$. haageana and their comparison with $M$. san-angelensis (Cactaceae)
}

\author{
Florencia Briones $^{1}$, Guadalupe Palomino ${ }^{1 *}$ and Armando Garcia ${ }^{2}$ \\ ${ }^{1}$ Instituto de Biología, Jardín Botánico, Universidad Nacional Autónoma de México, México D. F. 04510, México. \\ 2 Instituto de Recursos Genéticos y Productividad, Colegio de Posgraduados, carretera México - Texcoco, Km. 36.5. Montecillo, \\ Texcoco, Edo. De México. C. P. 56230
}

\begin{abstract}
This is the first report of chromosome number in Mammillaria supertexta, M. crucigera and M. haageana, which was the same in the three species: $2 \mathrm{n}=22, \mathrm{x}=11$. This number coincides with the number reported for the genus Mammilaria and for the Cactaceae family. However, interspecific variation was observed in the karyotypes: $M$. supertexta exhibited longer chromosomes (1.79-3.21 $\mathrm{m}$ ) and those of $M$. haageana were shorter (1.51-2.69 $\mu \mathrm{m})$; in M. crucigera the chromosomes were 1.63-2.74 $\mu \mathrm{m}$. The chromosomes of $M$. san-angelensis $(0.80-1.70 \mu \mathrm{m})$ are the shortest (PALOMino et al. 1999). Likewise, variation in the length of the haploid genome (LG) was observed: 26.84 $\mu \mathrm{m}$ for M. supertexta; of $23.81 \mu \mathrm{m}$ for M. crucigera; and $23.06 \mu \mathrm{m}$ for M. haageana. The LG of M. san-angelensis was shorter than that of the above species $(13.83 \mu \mathrm{m})$. The karyotypic formula for M. supertexta and M. crucigera was $10 \mathrm{~m}+1 \mathrm{sm}$, and in $M$. haageana it was $9 \mathrm{~m}+2 \mathrm{sm}$. A pair of chromosomes with satellites was observed in M. supertexta and M. haageana, and in M. crucigera two pairs of chromosomes were observed with satellites. Unlike these species, M. san-angelensis exhibited no sm chromosome; all were metacentric, and like M. crucigera, there were two pairs of chromosomes with satellites. The index of asymmetry calculated for $M$. supertexta was $43.44 \%$, for $M$. crucigera it was $42.55 \%$, and for $M$. haageana it was $42.71 \%$, indicating that the karyotypes were symmetric. The karyotype of $M$. baageana $(9 \mathrm{~m}+2 \mathrm{sm})$ was different from that determined for M. san-angelensis $(11 \mathrm{~m})$, thus showing divergence in its genomes. HUNT (1987) considers them to be synonymous, and complementary studies on morphology, hybridization, and cytogenetics are needed to determine the taxonomic category of these plants. M. haageana exhibited a total of 11 bivalents, a chiasmata frequency $(\mathrm{Fq})=13.86$ and a recombination index $(\mathrm{RI})=24.86$. These results are different from those of $M$. san-angelensis whose $\mathrm{Fq}=16.74$ and $\mathrm{RI}=27.74$. The higher $\mathrm{RI}$ in $M$. san-angelensis indicates that this species has more possibilities of forming new genetic combinations in its progeny and more opportunities of adapting to environmental changes than M. haageana with a lower RI. The interspecific variation observed among the four species of Mammillaria is possibly due to spontaneous structural changes in their chromosomes.
\end{abstract}

Key words: chromosome number, karyotype, Mammillaria.

\section{INTRODUCTION}

Mammillaria is the genus type of the Cactaceae family, and the taxonomic groups that it comprises have structural variability in the stem and flower, but mainly in the seed (Bravo-Hollis and SanchezMejorada 1991).

Evolutionarily, Mammillaria is the most recent genus of the Cactaceae family and is widely represented in the Mexican Republic; it is almost endemic in our country. Of a total of 166 species, 160 are found in Mexico, and of these 150 are endemic to

* Corresponding author: phone +5 6229045; fax +5 6229046; e-mail: hasbach@servidor.unam.mx this country, including the species M. supertexta, $M$. crucigera, and M. baageana (HUNT 1992, HERNANDEZ and Godínez 1994). The first two of these are considered vulnerable or threatened by extinction, according to the International Union for Conservation of Nature (IUCN).

Chromosome number has been reported in 155 species of the genus Mammillaria, establishing the basic number at $x=11$, like that of the Cactaceae family (Remski 1954; Sosa and Acosta 1966; Johnson 1980 and Palomino et al. 1999). Most of the diploid species are located in the Mexican Republic, where the center of origin and diversity of the genus is located (REMsKi 1954; Johnson 1978, 1980).

Within the subgenus Mammillaria, chromosome number has been determined in 30 species (REMSKI 1954; Pinkava and Mcleod 1971; Weedin and 
Powell 1978; Johnson 1978, 1980; Ross 1981; Gallagher and Parfitt 1982; Pinkava and ParFitT 1982; Gill and Goyal 1984 and Pinkava et al. 1985).

In the Supertextae series, there are reports of chromosome numbers ( $\mathrm{n}$ and $2 \mathrm{n}$ ) for four species: $M$. $r u$ estii, tetraploid species $(4 n=4 x=44)$ (REMSKI 1954), three diploid species $(2 \mathrm{n}=2 \mathrm{x}=22)$, M. vaupelii (REMSki 1954), M. lanata (GILl and Goyal 1984) and $M$. san-angelensis ( $\mathrm{n}=11 ; 2 \mathrm{n}=22$, PALOMINo et al. 1999).

The Supertextae series, belonging to the genus Mammillaria, comprises seven species, according to Hunt (1987). However, Bravo-Hollis and SANCHEz-MEJorAda (1991) believe that the series comprises 20 species. Of these, M. haageana is considered the valid species for the two systems, but HunT considers $M$. san-angelensis synonymous to $M$. haageana, while for Bravo-Hollis and SANCHEZ-MEJORADA, they are two different species. From this controversy is derived the interest in conducting the present study to contribute cytogenetic information to clarify this taxonomic situation.

This study reports the somatic chromosome number (2n) and karyotype of M. baageana, M. crucigera and $M$. supertexta and their meiotic behavior of $M$. haageana. A karyotypic comparative analysis between $M$. haageana and $M$. san-angelensis is also presented.

\section{MATERIALS AND METHODS}

Plant material - Plants of Mammillaria supertextae, $M$. crucigera and $M$. baageana were collected from wild populations in the Mexican states of Puebla and Oaxaca (Table 1). Live plants were transplanted and maintained in a greenhouse at the Jardín Botánico, Instituto de Biología, Universidad Nacional Autónoma de México (JBIBUNAM). Voucher specimens were deposited at the National Herbarium (MEXU) of the UNAM.
Mitotic chromosome analysis - For the observation of chromosome numbers $(2 n)$ and the karyotypes of the three species of Mammillaria, 9 to 15 mitotic cells at metaphase stage from 3 plants of each species were observed. Elongating secondary root tip cells were placed in a saturated solution of 1-Bromonaphthalene for $6 \mathrm{hr}$ at $18-20^{\circ} \mathrm{C}$ in darkness, then fixed in a $3: 1(\mathrm{~V} / \mathrm{V})$ Farmer mixture for $24 \mathrm{hr}$. The root tips were hydrolyzed with hydrochloric acid (1N) for $11 \mathrm{~min}$ at $60^{\circ} \mathrm{C}$ and transferred to Feulgen reagent for $2 \mathrm{hr}$, following GARCIA (1990) and Cid and PALOMINo (1996), procedures.

Slides were prepared using the squash technique; the best slides were frozen with dry ice (CONGER and FAIRCHIELD 1953) and mounted in Canada balsam. Three of the best cells in each population were photographed with Technical Pan Film using a Zeiss photomicroscope.

Karyotype analysis - The negative film was used to draw and measure chromosome arms and total genome length. Positions of centromeres were determined using a system of LeVAN et al. (1964); arm ratio ( $\mathrm{r}=$ long arm/ short arm) was calculated for each chromosome. Index of asymmetry (TF\%) was obtained following GUPTA and GuPTA (1978) procedure.

Meiotic chromosome analysis - Meiotic behavior was studied in pollen mother cells (PMC) from fresh anthers squashed in $1 \%$ aceto-orcein without prior fixation. A total of $32 \mathrm{MI}$ of PMC derived from three plants of $M$. baageana were analyzed. The following information was recorded: the type of bivalents (IIs), chiasmata frequency (Fq), and recombination index (RI) (WHITE 1973).

Pollen fertility - Estimates were made in samples of pollen stained with cotton blue in lactophenol. Percentages of well-filled stained grains were obtained from samples of 2900 pollen grain derived from three plants from each species.

Statistical analysis - The differences between the means of genome length and asymmetry indices (TF\%) in three species of Mammillaria were determined using one-way analysis of variance (ANOVA). Means were compared using the test of the minimal significant difference (MSD).

Table 1 - Provenance and karyotype analysis of Mammillaria supertexta, M. crucigera and M. haageana collected by Reyes and Briones.

\begin{tabular}{|c|c|c|c|c|c|c|}
\hline $\begin{array}{c}\text { Species } \\
\text { and locality }\end{array}$ & $2 n$ & $\begin{array}{c}\text { Karyotype } \\
\text { formula }\end{array}$ & $\begin{array}{l}\text { Number } \\
\text { of satellites }\end{array}$ & $\begin{array}{c}\text { Range } \\
\text { of chromosome } \\
\text { length }(\mu \mathrm{m})\end{array}$ & $\begin{array}{c}\text { Genome } \\
\text { length }(\mu \mathrm{m})\end{array}$ & $\begin{array}{c}\text { Index } \\
\text { of asymmetry } \\
(\mathrm{TF} \%)\end{array}$ \\
\hline $\begin{array}{l}\text { M. supertexta } \\
\text { México. Oaxaca } \\
\text { State. } 3851\end{array}$ & 22 & $10 \mathrm{~m}+1 \mathrm{sm}$ & $1 \mathrm{~m}$ & $1.79-3.21$ & 26.84 & 43.44 \\
\hline $\begin{array}{l}\text { M. crucigera } \\
\text { México. Puebla } \\
\text { State. } 3857\end{array}$ & 22 & $10 \mathrm{~m}+1 \mathrm{sm}$ & $2 \mathrm{~m}$ & $1.63-2.74$ & 23.81 & 42.55 \\
\hline $\begin{array}{c}\text { M. haageana } \\
\text { México. Oaxaca } \\
\text { State.3834 }\end{array}$ & 22 & $9 \mathrm{~m}+2 \mathrm{sm}$ & $1 \mathrm{~m}$ & $1.51-2.69$ & 23.06 & 42.71 \\
\hline
\end{tabular}




\section{RESULTS}

Chromosome number - The species Mammillaria supertexta, $M$. crucigera and $M$. haageana exhibited a diploid chromosome number $\mathbf{2 n}=\mathbf{2 x}=\mathbf{2 2}, \mathrm{x}=\mathbf{1 1}$, in M. haageana, $\mathbf{n}=\mathbf{1 1}$ was observed (Table 1; Figs.1 A, $\mathrm{B}$ and $\mathrm{C}$ ).

Chromosome length -In M. supertexta, chromosome length of 1.79 to $3.21 \mu \mathrm{m}$ was observed; the chromosomes of $M$. crucigera exhibited a length of 1.63 to $2.74 \mu \mathrm{m}$, and M.baageana had the shortest chromosomes, 1.51 a $2.69 \mu \mathrm{m}$. (Table 1 ).

Relative size was 6.67 to $11.96 \%$ for $M$. supertexta, 6.85 to $11.51 \%$ for M. crucigera, and 6.55 to $11.67 \%$ for M. baageana (Table 2).

Total chromosome length -The size of the chromosomes in the three species studied correlated with the total length of their genomes. The interval for genome length in the species studied was $23.06 \mu \mathrm{m}$ for $M$. baageana, which had the smallest value, and $26.84 \mu \mathrm{m}$ for M. supertexta, which had the highest. In M. crucigera genome length was $23.81 \mu \mathrm{m}$ (Table $1)$. Genome length was different in the three species $(\mathrm{P}<0.05)$.

Comparison of the karyotypes of the species, $M$. supertexta, M. haageana, M. crucigera and M. san-angelensis, based on the data of relative size ( $\mathrm{L} \%)$ and the arm ratio $(r)$ of their respective chromosome complements, indicated that, in spite of the differences, a certain uniformity in L\% can be observed among said species, with the exception of the chromosome pairs 1 and 4; 9,10 and 11 of $M$. san-angelensis: first two, which had a larger $\mathrm{L} \%$ and the last three with a smaller $\mathrm{L} \%$. In these pairs the differ-

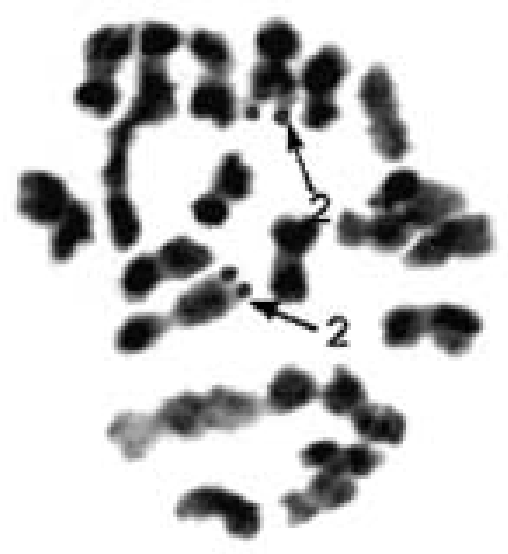

A
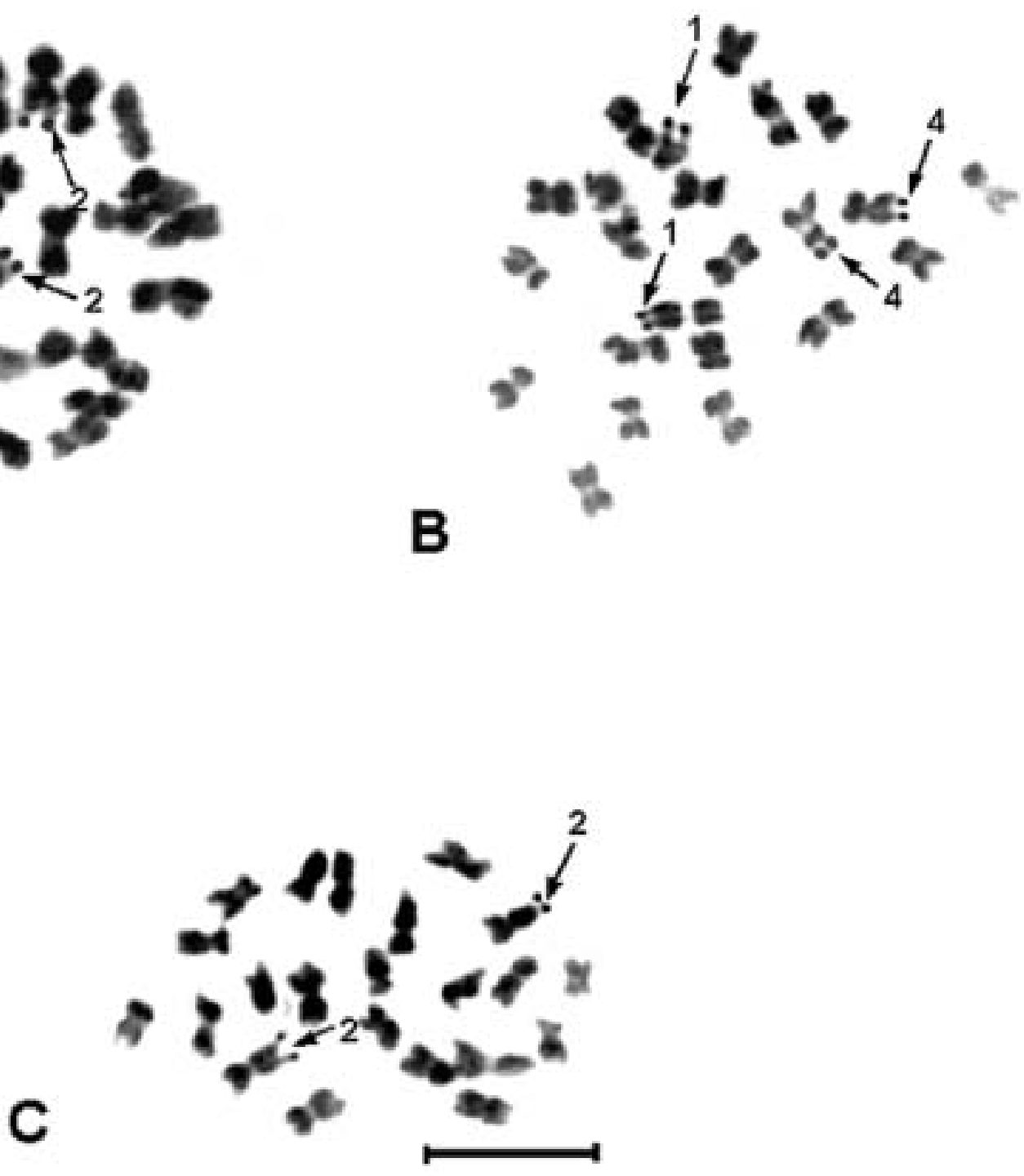

Fig. 1 - Somatic chromosomes, 2n=22, in Mammillaria: A) M. supertexta, B) M. crucigera y C) M. haageana. Numbers show chromosomes with satellites. Scale equals $10 \mu \mathrm{m}$. 
Table 2 - Relative length (L\%) and arm ratio ( $\mathrm{r}$ ) of somatic chromosomes of M. supertexta, M. crucigera, M. haageana and M. sanangelensis.

\begin{tabular}{ccccccccc}
\hline & \multicolumn{9}{c}{$(\mathrm{L} \%)$} & \multicolumn{3}{c}{$(r)$} \\
\hline $\begin{array}{c}\text { Chromosome } \\
\text { pair }\end{array}$ & $\begin{array}{c}\text { M. } \\
\text { supertexta }\end{array}$ & $\begin{array}{c}\text { M. } \\
\text { crucigera }\end{array}$ & $\begin{array}{c}\text { M. } \\
\text { haageana }\end{array}$ & $\begin{array}{c}\text { M. san- } \\
\text { angelensis }\end{array}$ & $\begin{array}{c}\text { M. } \\
\text { supertexta }\end{array}$ & $\begin{array}{c}\text { M. } \\
\text { crucigera }\end{array}$ & $\begin{array}{c}\text { M. } \\
\text { haageana }\end{array}$ & $\begin{array}{c}\text { M. san- } \\
\text { angelensis }\end{array}$ \\
\hline 1 & 11.96 & 11.51 & 11.67 & 12.30 & 1.17 & 1.17 & 1.12 & 1.36 \\
2 & 10.92 & 11.05 & 11.53 & 11.32 & 1.16 & 1.17 & 1.16 & 1.09 \\
3 & 10.73 & 10.16 & 10.23 & 10.48 & 1.18 & 1.26 & 1.17 & 1.08 \\
4 & 9.99 & 9.91 & 9.50 & 10.48 & 1.25 & 1.20 & 1.96 & 1.42 \\
5 & 9.46 & 9.45 & 9.50 & 9.76 & 1.29 & 1.21 & 1.26 & 1.08 \\
6 & 8.87 & 9.03 & 9.02 & 9.54 & 1.22 & 1.31 & 1.24 & 1.13 \\
7 & 8.31 & 8.60 & 8.67 & 8.46 & 1.21 & 1.24 & 1.25 & 1.25 \\
8 & 7.97 & 8.11 & 8.11 & 7.95 & 2.01 & 1.22 & 1.25 & 1.20 \\
9 & 7.82 & 7.73 & 7.80 & 7.23 & 1.23 & 1.22 & 2.05 & 1.00 \\
10 & 7.30 & 7.64 & 7.42 & 6.65 & 1.23 & 1.98 & 1.19 & 1.04 \\
11 & 6.67 & 6.85 & 6.55 & 5.78 & 1.29 & 1.29 & 1.22 & 1.00 \\
\hline
\end{tabular}

ence in $\mathrm{L} \%$ is notable, compared with the rest of the species (Table 2; Fig. 2).

Also, a certain homogeneity was observed in terms of arm ratio $(r)$, whose values indicated a predominance of metacentric chromosomes; again the chromosome pairs 1, 4, 9, 10, and 11 of $M$. san-angelensis departed from the behaviora pattern of the rest of the chromosome pairs of the other species. They are, however, also metacentric. The chromosome pairs 4 and 9 of $M$. haageana, 8 of M. supertexta, and 10 of M. crucigera had higher $\mathrm{r}$ values and are submetacentric (Table 2; Fig. 2).

Karyotype - The karyotype formulas of M. supertexta and M. crucigera were alike, corresponding to $10 \mathrm{~m}+1 \mathrm{sm}$. However, the submetacentric pair matched pair 8 in M. supertexta and 10 in M. crucigera. Unlike these two species, in $M$. haageana $9 \mathrm{~m}+2$ sm was observed (Table 1; Figs. 3 A, B y C).

Satellites- In the three species studied, satellites were observed. M. supertexta and M. baageana exhibited a pair of small spherical satellites measuring 0.40 and $0.33 \mu \mathrm{m}$, respectively, located in the short arms of metacentric chromosome pair 2. M. crucigera had two pairs of spherical satellites measuring 0.4 $\mu \mathrm{m}$ in the short arms of chromosomes 1 and 4 , both metacentric (Table 1; Figs. 1 A, B y C).

Asymmetry indices - The values obtained in the asymmetry indices (TF\%) of $M$. supertexta, M. crucigera and $M$. haageana were TF $\%=43.44,42.55$ and 42.71 , respectively (Table 1 ). There were no significant differences among the species in TF\% values $(\mathrm{P}>0.05)$.

Meiotic chromosome behavior- Meiotic behavior in $M$. haageana was normal. There were a total of 11 bivalents (II) (Fig.4) and one Fq per cell of 13.86 and per bivalent of 1.26 . The recombination index (RI) was 24.86 .

Pollen fertility- By using pollen stainability in cotton blue, all species have very high pollen stainability, M. supertexta $99.10 \%$, M. haageana $98.59 \%$ and M. crucigera $97.66 \%$, as expected for meiotic stability.

\section{DISCUSSION}

This report is the first communication of chromosome analysis in M. supertexta, M. crucigera and M. haageana (series Supertextae). The three species proved to be diploids $(\mathbf{2 n}=\mathbf{2 x}=\mathbf{2 2}, \mathrm{x}=\mathbf{1 1})$ and $\mathbf{n = 1 1}$ in $M$. haageana; the same basic chromosome number $(\mathrm{x}=11)$, indicated chromosome stability in the species. These characteristics coincide with those observed in other species of the same genus and series (Supertextae), such as M. vaupelii (Remski 1954), M.lanata (Gill and Goyal 1984), M. albilanata (Mohanty et al. 1996), and M. san-angelensis (PaLOMINO et al. 1999). These results corroborate $\mathrm{x}=11$, for the genus Mammillaria and the family Cactaceae (Sosa and Acosta 1966; Johnson 1980 and PaloMINo et al. 1999).

In M. supertexta, longer chromosomes (1.79 $3.21 \mu \mathrm{m}$ ) were observed; the chromosomes of $M$. crucigera were of intermediate length $(1.63-2.74 \mu \mathrm{m})$, and M.haageana had the shortest chromosomes (1.51 - $2.69 \mu \mathrm{m})$. In the species M. san-angelensis, PaLoMINo et al. (1999) determined a chromosome length of $0.80-1.70 \mu \mathrm{m}$ (Table 3). This confirms that the species $M$. supertexta, $M$. crucigera, $M$. haageana and M. san-angelensis, belonging to the series Supertex- 


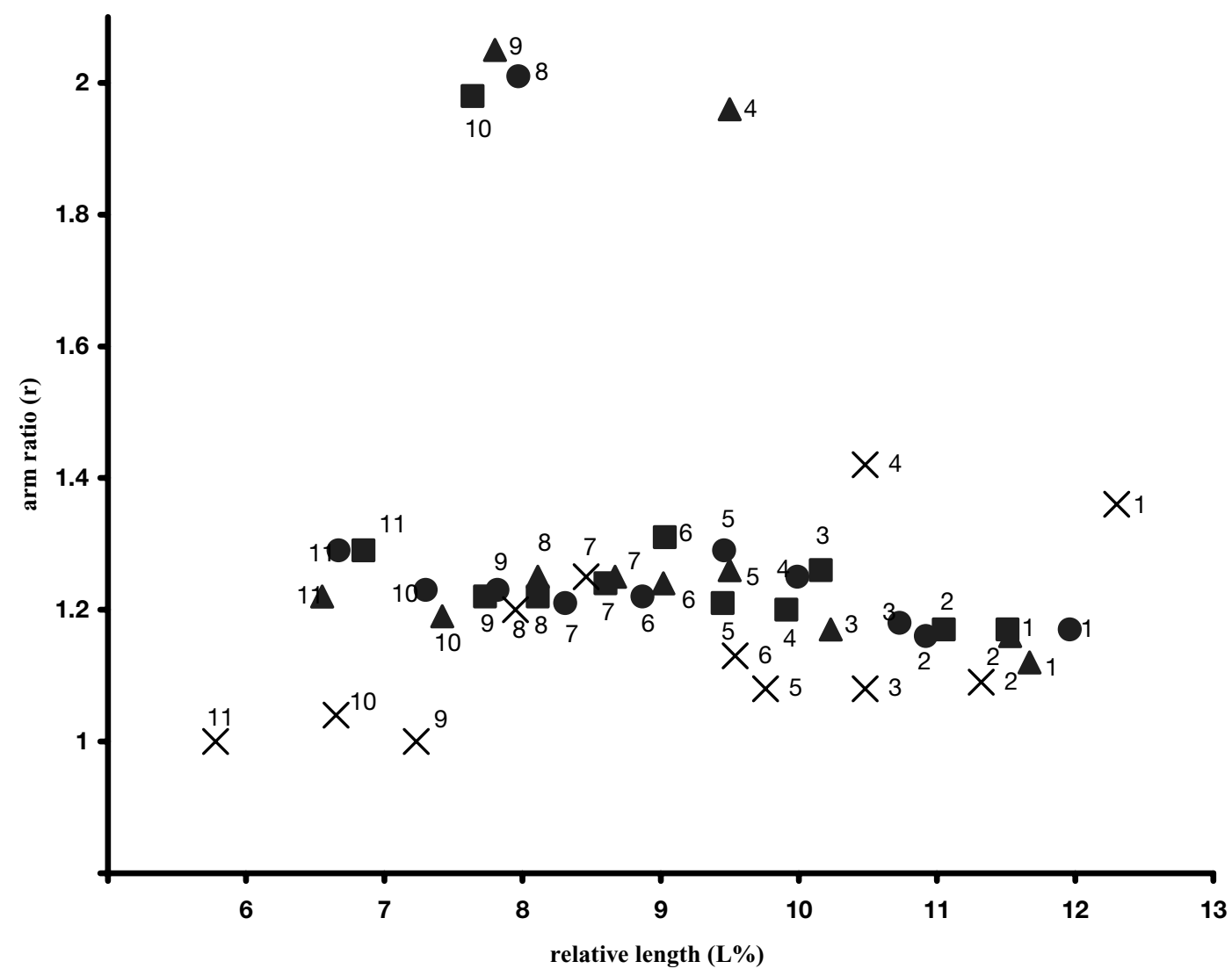

Fig. 2 - Graph of relative length (L\%) and arm ratio (r) of chromosome measurement in table 2. $\bullet$ M. supertexta,

$\boldsymbol{\Delta}$ M. haageana y X M. san-angelensis.

Table 3 - Karyotype analysis of Mammillaria supertexta, M. crucigera, M. baageana and M.san-angelensis*.

\begin{tabular}{ccccccc}
\hline Species & $2 \mathrm{n}$ & $\begin{array}{c}\text { Range of } \\
\text { chromosome } \\
\text { length }(\mu \mathrm{m})\end{array}$ & $\begin{array}{c}\text { Genome length } \\
(\mu \mathrm{m})\end{array}$ & $\begin{array}{c}\text { Karyotype } \\
\text { formula }\end{array}$ & $\begin{array}{c}\text { Number of } \\
\text { satellites }\end{array}$ & $\begin{array}{c}\text { Index of } \\
\text { asymmetry } \\
(\mathrm{TF} \%)\end{array}$ \\
\hline M. supertexta & 22 & $1.79-3.21$ & 26.84 & $10 \mathrm{~m}+1 \mathrm{sm}$ & $1 \mathrm{~m}$ & 43.44 \\
M. crucigera & 22 & $1.63-2.74$ & 23.81 & $10 \mathrm{~m}+1 \mathrm{sm}$ & $2 \mathrm{~m}$ & 42.55 \\
M. haageana & 22 & $1.51-2.69$ & 23.06 & $9 \mathrm{~m}+2 \mathrm{sm}$ & $1 \mathrm{~m}$ & 42.71 \\
M. san-angelensis & 22 & $0.80-1.70$ & 13.83 & $11 \mathrm{~m}$ & $2 \mathrm{~m}$ & 44.39 \\
\hline
\end{tabular}

* karyotype determined by PaLomino et al. 1999.

tae, vary among their genomes, and therefore there is interspecific variation.

When size of the chromosomes and length of the genome of the three species studied are compared with those of $M$. san-angelensis (PALOMino et al. 1999), the latter species had smaller chromosomes $(0.80-1.70 \mu \mathrm{m})$ and a $L G=13.83 \mu \mathrm{m}$, smaller than those observed in $M$. supertexta, $M$. crucigera and $M$. baageana (Table 3 ). These variations in genome length of the four species confirm the interspecific variability in the species of Mammillaria of the Supertextae series, which was determined previously by variation in total length of the pairs of chromosomes.
The differences in chromosome size of different species of the same genus are considered evidence of the restructuring of their genomes and are attributed to rearrangements of the chromosomes, such as deletions, duplications or translocations that occurred in the first stages of their evolution (PALOMINo et al. 1988; Cota and Wallace 1995; Cid and Palomino 1996).

Comparing $M$. haageana with $M$. san-angelensis in terms of $\mathrm{L} \%$ and $\mathrm{r}$ of their respective chromosome complements, minimum differences were observed among chromosomes 2, 7 and 8, in both $\mathrm{L} \%$ and $\mathrm{r}$, and maximum differences in chromosomes 1 , 


\section{|i|||||||||

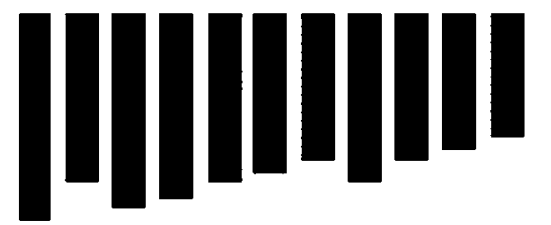

A

B

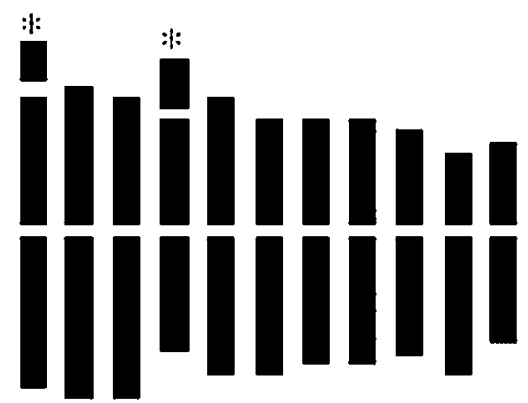

C

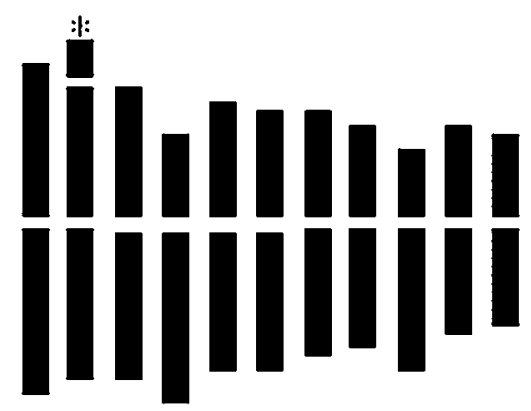

$\begin{array}{lllllllllll}1 & 2 & 3 & 4 & 5 & 6 & 7 & 8 & 9 & 10 & 11\end{array}$

Fig. 3 - Idiograms of three species of Mammillaria with $2 \mathrm{n}=22$. The numbers indicate the homologous chromosomes pairs: A) M. supertexta, $10 \mathrm{~m}+1 \mathrm{sm}$; B) M. crucigera, $10 \mathrm{~m}+1 \mathrm{sm}$ y C) $M$. haageana, $9 \mathrm{~m}+2 \mathrm{sm}$. Asterisks show chromosomes with satellites. Scale equals $1 \mu \mathrm{m}$.

4 and 9. In M. san-angelensis the 11 pairs of chromosomes were metacentric and there were no submetacentric pairs, while in $M$. baageana pairs 4 and 9 were submetacentric (Table 3; Fig. 2). These differences in $\mathrm{L} \%$ and $\mathrm{r}$ can be attributed to structural changes, such as deletions, duplications and translocations that have occurred during the evolution of their karyotypes.

The karyotypic formula of 10 pairs of metacentric and one pair of submetacentric chromosomes observed in $M$. supertexta and M. crucigera has also been determined in other species of Mammillaria such as M. boolii, M. bumboldtii, M.leucantha and $M$. woodsi (DAs et al. 1998a, 1999 b). The karyotypic formula $9 \mathrm{~m}+2 \mathrm{sm}$ that appeared in $M$. haageana has also been reported in $M$. bocasana, M. collinsii, $M$. mytax, M. geminispina, M. klisingiana, M. sempervivi and M. matudae (DAs et al. 1998a, 1999b and c).

The karyotypes of $M$. supertexta, $M$. crucigera and $M$. haageana are different from $M$. san-angelensis which, according to PALOMino et al. (1999), exhibited 11 metacentric chromosomes and no submetacentric chromosomes. It is evident that the four species belonging to the Supertextae series exhibit variation in the proportion of metacentric and submetacentric chromosomes. This variation has been observed by PaLOMino et al. (1988), CоTA and WALLACE (1995), and Cid and PAlomino (1996) in other species of cacti, and by DAs et al., (1998a), DAs et al., (1999b and 1999c) in other species of Mammillaria.

In the three species studied secondary constrictions were observed. Palomino et al. (1999), observed in M.san-angelensis, as in M. crucigera, 2 pairs of satellites on the short arm of the chromosome pairs 1 and 3 and 1 and 4, respectively. This variation could have been due to the occurrence of deletions, duplications, or translocation among the chromosomes (PAlomino et al. 1988; Cota and Wallace, 1995; Cid and Palomino 1996; Das et al. 1998a; DAs et al.1999b and c).

This variation in the number and position of satellites has also been reported in other species of Mammillaria that have 1-3 pairs of satellites on the chromosomes; 1 to 2 pairs are most often observed. Other genera of cacti, such as Melocactus (DAs et al. 1998 b, c) and Ferocactus (DAs et al. 1999 d) also have 1 to 3 pairs of chromosomes with satellites.

The values obtained in the asymmetry index (TF $\%$ ) of $M$. supertexta, $M$. crucigera and $M$. baageana were TF $\%=43.44,42.55$ y 42.71, respectively, similar to those obtained in $M$. geminispina ( $\mathrm{TF} \%=$ 42.55, DAs et al. 1998a), M. klissingiana (TF \% = 42.57, DAs et al.1999c), M. winteriae (TF \% = 43.03, DAs et al. 1999c) and M. bocasana (TF \% = 43.80, DAs et al. 1998a). In other Mammillaria species $\mathrm{TF} \%$ varied in the range of 35.50 to 49.19 , within which $\mathrm{TF} \%$ values were obtained for $M$. supertexta, M.crucigera and M. haageana; all of them coincide in having a symmetric karyotype.

Species of the genera Nyctocereus, (PALOMINo et al. 1988), Echinocereus (CotA and Wallace, 1995) and Myrtillocactus (CID and PALOMino 1996) also have symmetrical karyotypes and TF\% values similar to those observed in the genus Mammillaria.

Meiotic behavior in M. baageana was normal, had a total of 11 bivalents (II), and exhibited a Fq per cell of 13.86 and 1.26 per bivalent. The recombination index (RI) was 24.86. These results differ from those obtained by PALOMINo et al. (1999) for M. san-angelensis, whose Fq was 16.74 and its RI was 

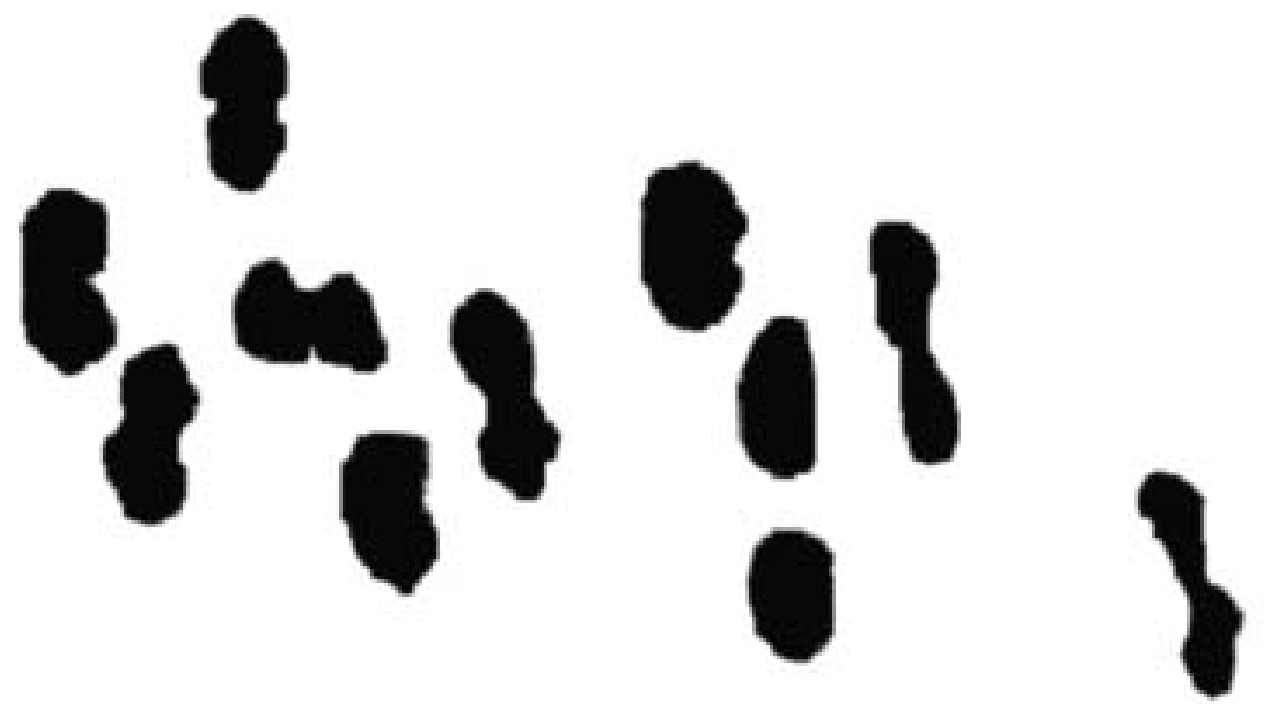

Fig 4. PMCs of Mammillaria haageana showing MI with 11 IIs. Scale equals $10 \mu \mathrm{m}$.

27.74. Being higher, these values mean that $M$. sanangelensis, has more possibilities of new genetic combinations in its progeny and, therefore, more opportunities of adaptation to environmental changes than $M$. baageana. Another species of the same series, $M$. albilanata, had a different Fq, 20.25 per cell and 1.84 per bivalent, which is within the ranges of 17.00-28.80 and 1.54-2.62, observed in other species of Mammillaria (Mohanty et al. 1996; DAs et al. 1997; Mohanty et al. 1997; Das et al. 1998a and DAs et al. 1999a).

The cytological analysis conducted in this work revealed an interspecific variation in $M$. supertexta, M. crucigera and M. haageana, as well as in M. san-angelensis (PALOMINo et al. 1999), species included in the Supertextae series (Table 3). Hunt (1987) considers $M$. haageana to be synonymous to $M$. san-angelensis. According to the cytological analysis of these two species, the two are different in both their karyotypes and their meiotic behavior: $M$. baageana chromosomes were longer $(1.51-2.69 \mu \mathrm{m})$ than those of $M$. san-angelensis (0.80-1.70 $\mu \mathrm{m})$. In addition, in $M$. san-angelensis the 11 pairs of chromosomes were metacentric, while in $M$. haggeana, 9 metacentric pairs and 2 submetacentric pairs were observed. Differences were also observed in their genomes in terms of the presence of chromosomes with satellites: $M$. baageana had 1 , and $M$. san-angelensis had 2. The Fq and RI values were lower in M. baageana, $\mathrm{Fq}=13.86$ and $\mathrm{RI}=24.86$, and higher in $M$. san-angel- ensis, $\mathrm{Fq}=16.74$ and $\mathrm{RI}=27.74$. Based on these results, divergence among the genomes is established, and therefore, complementary studies are needed to clarify the taxonomic category of the two species.

Acknowledgements - This study was supported by Jardín Botánico, IBUNAM. We are grateful to Jerónimo Reyes for his help in collecting Mammillaria plants, to Javier Martínez for the photographic work and statistical data analysis and Jorge Saldivar for assistance in the computerized edition of the manuscript.

\section{REFERENCES}

Bravo-Hollis H. and Sanchez Mejorada H., 1991 Las Cactáceas de México. Vol. 3 UNAM. México, D.F.

Cid R. and Palomino G., 1996 - Cytotypes and Meiotic behavior in mexican populations of Myrtillocactus geometrizans var. geometrizans (Cactaceae). Cytologia 61: 343-348.

Conger A. D. and Fairchield L. M., 1953 - A quickfreeze method for making smear slides permanent. Stain Techn. 28: 281-283.

Cota J. H. and Wallace R. S., 1995 - Karyotypic studies in the genus Echinocereus (Cactaceae) and their taxonomic significance. Caryologia 48 (2): 105-122.

Das A. B., Mohanty S. and Das P., 1997 - Meiotic behaviour and nuclear DNA variation in some species of Mammillaria (Cactaceae). Cytologia 62: 253-257. 
Das A. B., Mohanty S. and Das P., 1998a - Interspecific variation of nuclear DNA and structural changes in meiotic and mitotic chromosome in some species of Mammillaria (Cactaceae). Caryologia 51 (3-4): 289-301.

Das A. B., Mohanty S. and Das P., 1998b - Variation in karyotype and 4C DNA content in six species of Melocactus of the family Cactaceae. Cytologia 63: 9-16.

Das A. B., Mohanty S. and Das P., 1998c - Interspecific variation in nuclear DNA content and chromosome analysis in Melocactus. Cytologia 63: 239-247.

Das A. B., Mohanty S. and Das P., 1999a - Studies on chiasma frequency and nuclear 4C DNA amount in seven species of Mammillaria. Cytobios 97: 95-101.

Das A. B., Mohanty S. and Das P,. 1999b - Karyotype diversity in thirteen species of Mammillaria in the family Cactaceae. Cytobios 97: 117-125.

Das A. B., Mohanty S., Marrs R. H. and Das P., 1999c - Somatic chromosome number and karyotype diversity in fifteen species of Mammillaria of the family Cactaceae. Cytobios 97: 141-151.

Das A. B., Mohanty S. and Das P., 1999d - 4C DNA variations and Karyotype diversity in nine species of Ferocactus B. and R. Cytologia 64: 17-24.

Gallagher M. L. and Parfitt B. D., 1982 - In IOPB chromosome number reports LXXVII. Taxon 31: 761-762.

Garcia V. A., 1990 - Técnicas y Procedimientos de Citogenética Vegetal. Colegio de Postgraduados. 3 ed. Talleres gráficos de la Nación, México D. F. 144 pp.

Gill B. S. and Goyal V., $1984-$ Cytology of some members of Cactaceae. Cell. Chromosome Rev. 7: 58-60.

Gupta R. and Gupta P.K., 1978 - Karyotypic studies in the genus Crotalaria Linn. Cytologia, 43:357-369.

Hernandez M. H. and Godinez A.H., 1994 - Contribución al Conocimiento de las Cactáceas Mexicanas Amenazadas. Acta Botánica Mexicana 26: 33-52.

Hunt D., 1987. - A new review of Mammillaria. Bradleya 5: 45-48.

Hunt D., 1992 - CITES. Cactaceae checklist. Ed. Royal Botanical Garden Kew and International Organization for Succulent Plant Study (IOS). 190 pp.

Johnson M. A., 1978 - Diploid cytotypes in Mammillaria prolifera and three other Mammillaria species. Cact. and Succ. J. Gt. Brit. 40: 9-12.
JoHnson M. A., 1980 - Further cytological investigation in Mammillaria prolifera and other Mammillaria species. Cact. and Succ. J. Gt. Brit. 42 (2): 43-47.

Levan A., Fredga K. and Sandberg A. A., $1964-$ Nomenclature for centromeric position on chromosomes. Hereditas 52:201-220.

Mohanty S., Das A. B. and Das P., 1996 - Analysis of chiasma frequency and nuclear DNA variation in some species of Mammillaria. Cytobios 88: 173-181.

Mohanty S., Das A. B. and Das P., 1997 - Estimation of $4 C D N A$ content and determination of chiasma frequency in eight species of Mammillaria. Cytobios 91: 15-23.

Palomino H. G., Zuleta S. and Scheinvar L., 1988 - Estudios citogenéticos de dos especies y una variedad del género Nyctocereus (Cactaceae). Bol. Soc. Bot. México. 48: 75-79.

Palomino G., Dolezel J., Cid R., Brunner I., MenDEZ I. and Rubluo A., 1999 - Nuclear genome stability of Mammillaria san-angelensis (Cactaceae) regenerants induced by auxins in long term in vitro culture. Plant Science 141: 191-200.

Pinkava D. J. and Mcleod M. G., 1971 - Chromosome numbers in some cacti of western North America. Brittonia 23: 171-176.

Pinkava D. J., and Parfitt B. D., 1982 - Chromosome numbers in some cacti western North America IV. Bull. Torrey Bot. Club 109: 121-128.

Pinkava D. J., Parfitt B. D., Mohlebrock M. W. and Worthington R.D., 1985 - Chromosome numbers in some cacti western North America V. Syst. Bot. 10: 471-483.

Remski M. F., 1954 - Cytological investigations in Mammillaria and some associated genera. Bot. Gaz. 116 (2): 163-171.

Ross R., 1981 - Chromosome counts, cytology and reproduction in the Cactaceae. Am. J. Bot. 68: 463-470.

Sosa R. and Acosta A., 1966 - Poliploidia en Opuntia spp.. Agrociencia. Vol. 1 (1): 100-106.

Weedin J. F. and Powell A. M., 1978 - Chromosome number in Chibuabua desert Cactaceae. Trans Pecos Texas. Am. J. Bot. 65: 531-537.

White M., 1973 - Animal Cytology and Evolution. Cambridge University (ed.), 961p.

Received September 12, 2003; accepted January 26, 2004 